\title{
KOMITMEN MAHASISWA MANAJEMEN PENDIDIKAN KRISTEN DALAM MENYELESAIKAN STUDI
}

\author{
Betty Arli Sonti Pakpahan \\ Prodi Manajemen Pendidikan Kristen, Institut Agama Kristen Negeri Tarutung
}

\begin{abstract}
This study aims to determine university student's commitment in completing studies in the department Christian education management at IAKN Tarutung. Participants involved were studying at the third semester. Data were collected through a qualitative approach including from interview, documents, and open questionnaires. The results showed; First, students have commitment completing their studies although they were disappointed when they learned that their graduation was not in accordance with their first choice, but due to parents' advice and motivation, the socialization process and learning from lecturers, the motivation of classmates, student involvement in various campus activities, students increasingly love their study programs. Second, there is no significant difference between students who purely choose Christian education management study programs and students who graduate based on second choice and transition from other study programs. The results of this study indicate that intellectual desires and abilities are not the main key in completing studies but because of hard work, and strong commitment (strong determination).
\end{abstract}

Keywords: Commitment, Students, Completing Studies

\begin{abstract}
ABSTRAK
Penelitian ini bertujuan untuk mengetahui komitmen mahasiswa Prodi Manajemen Pendidikan Kristen dalam menyelesaikan studi di IAKN Tarutung. Subjek penelitian adalah mahasiswa semester tiga Prodi Manajemen Pendidikan Kristen. Data penelitian diperoleh melalui pendekatan kualitatif dengan metode wawancara, dokumen dan angket terbuka. Hasil penelitian menunjukkan; pertama, mahasiswa berkomitmen untuk menyelesaikan studinya di IAKN Tarutung walaupun pada awalnya merasa kecewa ketika mengetahui kelulusannya tidak sesuai dengan pilihan pertamanya, namun karena faktor nasehat dan motivasi orangtua, proses sosilaisasi dan pembelajaran dari dosen, motivasi teman kuliah, keterlibatan mahasiswa dalam berbagai kegiatan kampus, mahasiswa semakin mencintai prodinya, Kedua, tidak ada perbedaan yang signifikan antara mahasiswa yang murni memilih prodi manajemen pendidikan kristen dengan mahasiswa yang lulus berdasarkan pilihan kedua dan peralihan dari prodi lain. Hasil penelitian ini menunjukkan bahwa keinginan dan kemampuan intelektual tidak menjadi kunci utama dalam menyelesaikan studi tetapi oleh karena kerja keras, dan komitmen yang kuat (tekat yang kuat).
\end{abstract}

Kata Kunci: Komitmen, Mahasiswa, Menyelesaikan Studi

9 | Korespondensi mengenai artikel dapat dilakukan kepada: Betty Arli Sonti Pakpahan, Prodi Manajemen Pendidikan Kristen, Institut Agama Kristen Negeri Tarutung, Jl. Raya Tarutung-Siborong KM 11, Silangkitang, Sipoholon, Tapanuli Utara (22452), Indonesia

E-mail Corresponding: bas.pakpahan@yahoo.com 


\section{PENDAHULUAN}

Lulus di perguruan tinggi sesuai dengan keinginan merupakan idaman setiap orang, karena keinginan akan mengarahkan seseorang pada perbuatan pencapaian tujuan. Menurut Djaali (2007: 99), "keinginan yang kuat terhadap sesuatu merupakan modal besar untuk mencapai tujuan" Keinginan yang besar tersebut dengan sendirinya akan mendorong seseorang untuk lebih memusatkan perhatiannya terhadap sesuatu yang dimaksud. Namun kenyataan menunjukkan bahwa banyak sekali mahasiswa yang salah dalam memilih jurusan. Berdasarkan hasil penelitian Indonesia Career Center Network (ICCN) tahun 2017, sebanyak $87 \%$ mahasiswa Indonesia mengakui bahwa jurusan yang mereka ambil tidak sesuai dengan minatnya. Persentase ini sangat besar, sekaligus ironi bahwa sebagian besar mahasiswa Indonesia ternyata tidak sesuai dengan minat atau passion yang diinginkan (http://news.unair.ac.id/2017).

Ada beberapa faktor yang mempengarugi seseorang salah memilih jurusan antara lain: keinginan orangtua, ikut-ikutan dengan teman, kalah dalam pilihan pertama dan faktor ekonomi. Berdasarkan data pendaftar dan yang lulus calon mahasiswa berdasarkan prodi tahun 2018 dan 2019 pada IAKN Tarutung dapat dilihat pada tabel 1 .

Tabel 1. Data Pendaftar dan Kelulusan Calon Mahasiswa Berdasarkan Prodi Tahun 2018 dan 2019 di IAKN Tarutung

\begin{tabular}{llccllcc}
\hline & \multicolumn{3}{c}{ Tahun 2018 } & \multicolumn{3}{c}{ Tahun 2019 } \\
\hline No. & Prodi & Pendaftar & Lulus & No. & Prodi & Pendaftar & Lulus \\
1 & PAK & 149 & 83 & 1 & PAK & 323 & 260 \\
2 & PMG & 27 & 25 & 2 & PMG & 39 & 35 \\
3 & PAUD & 20 & 25 & 3 & PAUD & 46 & 44 \\
4 & MPK & 10 & 27 & 4 & MPK & 51 & 56 \\
5 & TEOLOGI & 36 & 35 & 5 & TEOLOGI & 66 & 61 \\
6 & PK & 11 & 4 & 6 & PK & 12 & 23 \\
7 & MISSIOLOGI & 1 & 8 & 7 & MISSIOLOGI & 1 & - \\
8 & PARIWISATA & 2 & 6 & 8 & PARIWISATA & 52 & 51 \\
9 & MKK & 2 & 6 & 9 & MKK & 48 & 39 \\
10 & SOSIOLOGI & 10 & 23 & 10 & SOSIOLOGI & 13 & 18 \\
& Jumlah & $\mathbf{3 7 9}$ & $\mathbf{3 5 3}$ & & Jumlah & $\mathbf{6 3 9}$ & $\mathbf{5 8 7}$ \\
\hline
\end{tabular}

\section{Sumber: Dokumen Pendaftaran di IAKN Tarutung}

Berdasarkan tabel di atas dapat dilihat bahwa sebagian mahasiswa lulus berdasarkan pilihan ke dua dan peralihan dari prodi lain. Hal ini terlihat dari jumlah pendaftar dengan yang lulus di sebahagian prodi. Secara logika hal ini tidak masuk akal, tetapi dengan pertimbangan pemenuhan pembukaan kelas baru untuk beberapa prodi, maka pada saat wawancara ada tawaran bagi calon mahasiswa jika tidak lulus pada pilihan pertama apakah bersedia masuk pada pilihan kedua atau diluar dari pilihan yang telah ditetapkan. Kenyataan inilah yang mengakibatkan jumlah yang lulus lebih banyak dari jumlah pendaftaran pada sebagian prodi. 
Salah satu prodi yang mengalami fenomena di atas adalah prodi manajemen pendidikan Kristen sebagai salah satu prodi di Fakultas Ilmu pendidikan yang telah menerima mahasiswa baru tahun 2018, dan jumlah mahasiswa yang terseleksi sebanyak 27 orang dari 10 orang pendaftar. Namun setelah ditelusuri dokumen pendaftaran mahasiswa prodi manajemen pendidikan Kristen, penulis menemukan bahwa jumlah yang ditempatkan sebanyak 30 orang, 7 orang yang murni memilih prodi manajemen, 16 orang memilih manajemen sebagai pilihan kedua dan 7 orang peralihan dari prodi lain (sama sekali tidak memilih prodi manajemen).

Namun perlu diketahui bahwa tidak menjadi jaminan seseorang mahasiswa yang mengambil jurusan sesuai keinginanya akan mendapatkan pekerjaan yang cocok dengan bidang ilmu yang ditekuninya. Begitu juga dengan mahasiswa yang salah jurusan, belum tentu mendapatkan pekerjaan yang tidak dia sukai, yang penting calon mahasiswa harus benar-benar menyadari keputusan yang diambil dan siap menerima konsekuensi dari keputusannya. Kesadaran calon mahasiswa dalam menentukan pilihan berdampak pada tindakan, sehingga tidak ada keterpaksaan dalam mengerjakan kewajibannya. Jika sesuatu dikerjakan dengan terpaksa, maka hasilnya tentu kurang maksimal selain bisa menimbulkan penyesalan. Mahasiswa harus berkomitmen dan bekerja keras, berjuang bahkan harus berkorban dalam pencaian tujuan dari hasil keputusannya.

Komitmen pada diri sendiri sangat penting, karena komitmen merupakan keinginan yang kuat untuk mencapai sesuatu, keteguhan hati, tekad yang kuat dan janji untuk melakukan atau mewujudkan sesuatu yang diyakini.Komitmen pada diri sendiri merupakan bentuk komitmen yang berlandaskan adanya keinginan yang kuat dari diri sendiri untuk mencapai sesuatu yang lebih baik. Sehingga seseorang mahasiswa yang menetapkan suatu pilihan yang diyakininya sejak awal akan bertekat untuk selesai tepat waktu, Sebagaimana dikemukakan oleh Arlene Blum, "Imbalan terbesar hanya datang dari komitmen terbesar".

Seseorang akan berhasil mencapai cita-citanya apabila ada janji, atau tekat yang kuat pada dirinya sendiri, sehingga tekat yang kuat akan mendorong seseorang bertindak sesuai yang diinginkan. Komitmen merupakan sebuah kesanggupan diri untuk mengkaitkan antara niat, tekad dan perbuatan. Artinya komitmen harus diwujudkan dalam tindakan yang aktif, bukan hanya sebatas niat dalam pikiran (pasif). Steers dan porter mengatakan bahwa suatu bentuk komitmen yang muncul bukan hanya loyalitas yang pasif, tetapi juga melibatkan hubungan yang aktif dengan sesuatu yang telah ditekadkan, memiliki tujuan, memberikan segala usaha demi mencapai tujuan. Mahasiswa yang memiliki komitmen akan setia pada keputusanya, bekerja keras untuk mencapai citacitanya, mematuhi peraturan yang ditetapkan oleh lembaga, menyediakan

11 | Komitmen Mahasiswa Manajemen Pendidikan Kristen dalam..., Pakpahan, Betty Arli Sonti Jurnal Christian Humanioran | http://e-journal.iakntarutung.ac.id/index.php/humaniora 
waktunya untuk belajar dan bersedia berkorban untuk kepentingan pribadi dan prodinya.

Namun bagaimana komitmen seorang mahasiswa yang lulus berdasarkan pilihan kedua dan berdasarkan peralihan dari prodi yang lain atau dengan kata lain mahasiswa kuliah karena dorongan orangtua, atau ikut-ikutan teman, sebab pemilihan prodi yang tepat atau sesuai akan menunjang proses penyelesaian studi di perguruan tinggi. Berdasarkan uraian diatas, maka peneliti tertarik untuk melakukan penelitian mengenai komitmen mahasiswa manajemen pendidikan kristen dalam menyelesaikan studi di IAKN Tarutung, sekaitan dengan berbagai kebijakan lembaga. Dengan fokus masalah: 1) Bagaimana komitmen awal mahasiswa memilih prodi manajemen pendidikan kristen IAKN Tarutung, 2) Bagaimana komitmen mahasiswa prodi manajemen setelah mengikuti perkuliahan, 3) Faktor apa yang mempengaruhi komitmen mahasiswa dalam menyelesaikan studi di IAKN Tarutung dan 4) Apakah komitmen awal mahasiswa prodi manajemen pendidikan kristen berdampak terhadap hasil perkuliahaan.

Komitmen adalah suatu keadaan dimana seseorang membuat perjanjian (keterikatan baik kepada diri sendiri maupun kepada orang lain yang tercermin dalam tindakan/perilaku tertentu yang dilakukan secara sukarela maupun terpaksa. Menurut Steers dan Porter (dalam Sopiah, 2008), pengertian komitmen adalah suatu keadaan dimana individu menjadi terikat oleh tindakannya sehingga akan menimbulkan keyakinan yang menunjang aktivitas dan keterlibatanya. Pengertian ini menjelaskan bahwa seseorang yang berkomitmen akan terikat dengan yang diikrarkannya dan bertekat untuk mencapainya dengan berbagai cara yang dapat menunjang harapannya. Perasaan keterikatan itu memotivasi individu untuk bertingkahlaku secara baik dan melakukan tindakan yang tepat pada dirinya sendiri.

Menurut Meyer dan Herscovitch, bahwa komitmen sebagai suatu kekuatan yang mengikat individu untuk melakukan aksi yang relevan dengan sasaran tertentu. Komitmen juga diartikan suatu bentuk kewajiban yang mengikat seseorang dengan sesuatu, baik itu diri sendiri maupun orang lain, tindakan tertentu, atau hal tertentu. komitmen merupakan suatu sikap setia dan tanggungjawab seseorang terhadap sesuatu. Komitmen disebut juga sebagai tekat yang kuat, kemauan yang tinggi untuk melakukan sesuatu. Menurut Jenny, komitmen adalah sesuatu yang membuat individu rela membulatkan hati dan tekad demi mencapai suatu tujuan, sekalipun individu belum dapat mengetahui hasil akhir dari tujuan tersebut.

Komitmen bermula dari dalam diri, dan bertumbuh dari niatan baik yang dibiasakan setiap hari, setiap waktu sehingga menjadi suatu kebiasaan yang didalamnya terdapat tanggung jawab dan kepercayaan terhadap sesuatu hal. Sesuatu yang berasal dari dalam diri, tidak akan mudah berubah hanya karena faktor eksternal, tetapi bila tujuan tidak berasal dari dalam diri pembuat 
komitmen, maka akan sangat mudah goyah dengan situasi dan kondisi, sehingga keyakinan dan tanggungjawab menjadi komitmen sementara. John C. Maxwell (2001), menjelaskan beberapa sifat dari komitmen, yakni; (1) komitmen dimulai di dalam hati; (2) komitmen diuji oleh perbuatan; (3) komitmen membuka pintu menuju atau mendahului setiap prestasi; (4) komitmen adalah musuh dari penolakan, karena komitmen adalah janji serius untuk terus maju dan bangkit. Ciri-ciri komitmen adalah 1) adanya perjanjian yang disepakati, baik terhadap diri sendiri maupun terhadap pihak lain, 2) terdapat tujuan atau goal tertentu yang ingin dicapai setelah melaksanakan komitmen, 3) bertanggungjawab dengan isi perjanjianya, 4) adanya kesetiaan dari dirinya terhadap tujuan yang ingin dicapai. Komitmen pada diri sendiri dapat ditumbuhkan dengan cara sebagai berikut: 1) ketabahan; kuat hati dalam menghadapi cobaan dan kesulitan hidup, 2). Keuletan, dan 3) disiplin.

Menurut Paryati S.(2004). Mahasiswa berasal dari terjemahan "student" yang berarti "a person who studies or investigates" yaitu seseorang yang belajar dan meneliti, dan "to study" adalah menggunakan akal pikiran secara aktif dan cermat serta penuh dengan perhatian untuk dan dapat memahami suatu ilmu pengetahuan. Dengan kata lain mahasiswa atau student harus aktif belajar secara mandiri maupun dengan bimbingan dan arahan dosen. Dalam Undang-Undang Republik Indonesia Nomor 12 Tahun 2012 tentang Pendidikan Tinggi disebutkan bahwa mahasiswa adalah peserta didik pada jenjang pendidikan tinggi. shingga mahasiswa sering juga disebut "golongan intelektual muda" yang penuh bakat dan potensi. Menurut Yusuf, seorang mahasiswa dikategorikan pada tahap perkembangan yang usianya 18 sampai 25 tahun, yang memiliki tujuan ingin mencapai dan meraih taraf keilmuan yang matang, menguasai sesuatu ilmu, serta memiliki wawasan ilmiah yang luas sehingga mampu bersikap dan bertindak ilmiah dalam segala hal yang berkaitan dengan keilmuanya untuk diabdikan kepada masyarakat dan umat manusia. Mahasiswa yang dimaksud dalam penelitian ini adalah orang yang terdaftar dan belajar di perguruan tinggi IAKN Tarutung, yang umumnya berusia antara 18 - 21 tahun untuk program S1.

Menyelesaikan studi di perguruan tinggi adalah sebuah keniscayaan. Penyelesaian tersebut ditandai dengan pengelolaan yang efektif dan efisien. Efektif itu diukur dari seberapa besar mahasiswa melakukan proses pembelajaran di perguruan tinggi dan memiliki hard skill dan soft skill sebagai hasil pembelajaran, sedangkan efisien diukur dari tingkat lama mahasiswa dalam menyelesaikan studinya. Berdasarkan Permendikti nomor 44 tahun 2015, paling lama 7 (tujuh) tahun akademik untuk program sarjana, program diploma empat/sarjana terapan, dengan beban belajar mahasiswa paling sedikit 144 sks. Untuk mencapai efektivitas dan efisiensi dibutuhkan pola manajemen yang baik

13 | Komitmen Mahasiswa Manajemen Pendidikan Kristen dalam..., Pakpahan, Betty Arli Sonti Jurnal Christian Humanioran | http://e-journal.iakntarutung.ac.id/index.php/humaniora 
dan komitmen yang tinggi dari mahasiwa maupun pihak pengelola perguruan tinggi dalam mengelola proses akademik di kampus.

\section{METODE PENELITIAN}

Penelitian ini menggunakan metode kulalitatif dan pendekatan fenomenologis, dengan lokasi penelitian Institut agama Kristen Negeri (IAKN) Tarutung, subjek penelitian: a) Mahasiswa, b) Dosen, c. Ketua Prodi Manajemen Pendidikan Kristen dan dokumen. Pengumpulan data dengan: a) Wawancara, b) angket terbuka dan Dokumentasi: Analisa data mencakup: a) Reduksi data: b) Penyajian Data: c) Conculusion Drawing/verivication.

\section{HASIL DAN PEMBAHASAN}

Berdasarkan hasil wawancara dan angket terbuka untuk pertanyaan 1 kepada mahasiswa, bahwa pada umumnya mahasiswa merasa kecewa, ketika tidak lulus sesuai keinginanya, tetapi karena faktor dukungan, motivasi dan nasehat orangtua mahasiswa tetap bertahan mengikuti perkuliahan di prodi manajemen, sekalipun ada mahasiswa merasa terpaksa.

Hasil wawancara dan angket terbuka untuk pertanyaan II kepada mahasiswa, bahwa pada umumnya mahasiswa semakin betah kuliah diprodi manajemen, setelah mahasiswa mendapat pengetahuan dan pemahaman tentang profil dari prodi melalui proses sosialisasi dan pembelajaran. Hal ini menunjukkan bahwa pengetahuan tentang sesuatu akan mendorong seseorang bertekat mencapainya, sebagaimana dikemukakan oleh Meyer dan Herscovitch (2001), bahwa faktor sosialisasi dapat menumbuhkan komitmen, Robbins S., 2008) proses sosialisasi menumbuhkan komitmen dan Colquit, (2009), mengemukakan pembelajaran dan pengambilan keputusan berdampak pada komitmen.

Hasil wawancara dan angket terbuka untuk pertanyaan 3 kepada mahasiswa, bahwa factor yang mempengaruhi mahasiswa semakin berkomitmen dalam menyelesaikan studi di prodi Manajemen pendidikan Kristen, antara lain teman kuliah, dosen, orangtua, peluang kerja, disiplin, tugas yang menantang dan keterlibatan dalam kepengurusan organisasi mahasiswa. Hal yang sama juga menjadi temuan dari informan Pastoral kaunsling dan Teologi, hanya ada factor yang berbeda yakni factor ibadah. Namun dari factor yang paling dominan adalah teman kuliah. Temuan ini menunjukkan bahwa dalam menyelesaikan studi tidak selalu berdasarkan komitmen dari diri sendiri tetapi komitmen itu juga dapat timbul dari luar diri antara lain motivasi keluarga, dukungan teman, pembelajaran dan lain-lain, sebagaimana dikemukakan oleh Paryati S.(2004), keberhasilan belajar di perguruan tinggi dipengaruhi oleh minat dan bakat, motivasi diri yang kuat, mengetahui tujuan yang hendak dicapai, mempersiapkan belajar dengan baik, merencanakan kegiatan akademik dan disiplin diri, sarana dan prasarana yang baik, lingkungan belajar yang mendukung dan mengetahui cara kerja otak.

14 | Komitmen Mahasiswa Manajemen Pendidikan Kristen dalam..., Pakpahan, Betty Arli Sonti Jurnal Christian Humanioran | http://e-journal.iakntarutung.ac.id/index.php/humaniora 
Hasil yang dicapai oleh mahasiswa prodi manajemen yang lulus berdasarkan pilihan pertamanya dan yang lulus berdasarkan pilihan kedua atau peralihan dari prodi lain tidak ada perbedaan yang signifikan dilihat dari IPK semester I dan II. Hal ini menegaskan bahwa keinginan dan kemampuan intelektual tidak menjadi kunci utama dalam menyelesaikan studi tetapi kerja keras, tekat yang kuat akan mempermudah mahasiswa menyelesaikan studi. Sebagaimana dikatakan Arlene Blum (2012), "Imbalan terbesar hanya datang dari komitmen terbesar". Komitmen memberi kekuatan dalam bertindak yang memungkinkan mahasiswa mampu menyelesaikan studi di perguruan tinggi. Komitmen tidak tergantung pada keinginan, bakat dan kemampuan tetapi dapat dibangun dalam diri individu. Komitmen timbul karena pilihan, bukan karena kondisi, dan komitmen akan kekal jika didasarkan pada nilai-nilai kebenaran. Jika mahasiswa membuat pilihan yang di dasarkan pada nilai kebenaran, nilai kehihudapan yang mantap, akan berada pada posisi yang lebih baik untuk mempertahankan komitmennya. Komitmen dengan nilai-nilai kebenaran ditindak lanjuti dengan tindakan, perbuatan, perjuangan dan pengorbanan dan siap mengambil resiko.

\section{KESIMPULAN DAN SARAN}

Komitmen mahasiswa prodi manajemen semester III, awalnya belum mantap karena tidak sesuai dengan pilihannya. Setelah berproses selama 3 semester, komitmen mahasiswa mulai timbul dan semakin bertekad untuk menyelesaikan kuliah bahkan ada sebagian yang ingin studi lanjut. Faktor yang sangat dominan mempengaruhi mahasiswa semakin berkomitmen menyelesaikan studi Prodi Manajemen Pendidikan Kristen adalah factor teman kuliah yang saling memahami, saling kerjasama dan saling mendukung, selanjutnya factor dosen, orangtua, peluang kerja, disiplin, tugas yang menantang dan keterlibatan dalam kepengurusan organisasi mahasiswa. Prestasi belajar mahasiswa yang murni memilih manajemen. Pendidikan Kristen dengan mahasiswa yang lulus berdasarkan pilihan kedua dan yang sama sekali tidak memilih MPK, tidak ada perbedaan yang signifikan. Berdasarkan empat temuan di atas, maka simpulanya adalah Komitmen mahasiswa pada awal perkuliahan belum kuat, tetapi dengan motivasi dan dukungan keluarga, dosen dan teman kuliah, mendorong mahasiswa semakin bertekad untuk menyelesaikan studi di IAKN Tarutung. Hal ini menegaskan bahwa keinginan dan kemampuan intelektual tidak menjadi kunci utama dalam menyelesaikan studi tetapi oleh karena kerja keras, dan komitmen yang kuat (tekat yang kuat). Komitmen tidak tergantung pada keinginan, bakat dan kemampuan tetapi dapat dibangun dalam diri individu. Jika Komitmen mahasiswa sudah terbangun dalam dirinya maka mahasiswa akan bekerja keras untuk menyelesaikan studinya.

15 | Komitmen Mahasiswa Manajemen Pendidikan Kristen dalam..., Pakpahan, Betty Arli Sonti Jurnal Christian Humanioran | http://e-journal.iakntarutung.ac.id/index.php/humaniora 
Bagi mahasiswa yang merasa salah pilih jurusan, jangan kuatir dalam penyelesaian studi. Karena keberhasilan seseorang dalam mencapai cita-citanya tidak hanya didasarkan keinginan melainkan juga karena kemauan dan ketekunan belajar, pengorbanan, tekat yang kuat serta keyakinan diri.

\section{DAFTAR PUSTAKA}

Ginting, C. 2003. Kiat Belajar di Perguruan Tinggi. Jakarta: Grasindo.

Cald. 2008. Cambridge Advanced Learner's Dictionary. Cambridge: Cambridge University Press.

Djaali. 2007. Psikologi Pendidikan. Jakarta: Bumi Aksara.

Greenberg, Jerald \& Robert A. Baron. 2000. Behaviour in Organization. London: Prentice Hall.

Guba, E. G. \& Lincoln, Y.S. 2005. The Sage Handbook of Qualitative Research ( $3^{\text {rd }}$ edition). Thousand Oaks, CA: Sage.

http://news.unair.ac.id/2017/12/21/antara-passion-pekerjaan-dan-jurusansanggupkah-memilih-ketiganya

James M. Kouzes, barryz. Posner. 2012. The Leadership Challenge $5^{\text {th }}$ : How to Make Extraordinary Things Happen in Organizations. USA: Jossey-bass.

Jason A. Colquitt, Jeffery A LePine, Michael J.Wesson,. 2009. Organizational Behavior. Improving Performance and Commitment in the Workplace Singapore: McGraw-Hill

J.D.Douglas, Ensiklopedi Alkitab Masa kini, Jilid II (M-Z). Jakarta: Yayasan Komunikasi Bina kasih/OMF

Jenny, J. 2009, Komitmen, http//www.jakartalarnten.com. Diunduh

Lexy J.Moleong. 2012. Metode Penelitian Kualitatif Edisi Revisi, Bandung, Remaja Rosdakarya.

Meyer dan Hercovitch. 2001. Commitment in the Workplace:Toward a General Model. London: Blackwell Scientific Publication.

Medium.com/@suryaprayogaa/komitme

Miles, M. B, Humberman,A.M. dan saldana,J.2014. Qualitaive Data Analysis A Methods Sourceboo. Edition 3. USA: Sage Publications. Terjemahan Tjetjep Rohindi Rohidi,UI-Press.

Pasaribu, Arifin, Khairul. 2016. Cara Menumbuhkan Komitmen Pada diri Sendiri dan Pada Orang Lain.Kreatifitasanakeki,blogsppot.com.

Robert Kreitner \& Angelo Kinicki. 2007. Organizational Behavior. Seventh Edition. USA: Mc. Graw Hill Companies,

Sopiah. 2008. Perilaku Organisasi, Yokyakarta, Andi

Covey, S. R. 1994. 7 Kebiasaan Manusia Yang Sangat Efektif (The Seven Habits Of Highly Effective People). Budijanto. Jakarta: Binarupa Aksara

Sugiyono. 2013. Metode Penelitian Pendidikan Kuantitatif, Kualitatif dan R\&D. Bandung: Alfabeta,

16 | Komitmen Mahasiswa Manajemen Pendidikan Kristen dalam..., Pakpahan, Betty Arli Sonti Jurnal Christian Humanioran | http://e-journal.iakntarutung.ac.id/index.php/humaniora 
Undang-Undang Pendidikan Tinggi 2012 (UU RI N0.12 tahun 2012). Jakarta: Sinar Graafika.

Versi offline dengan mengacu pada data KBBI, diambil dari http://pusatbahasa.diknas.go.id/KBBI

Yusuf. 2012. Psikologi Perkembangan Anak dan Remaja, Bandung, Remaja Rosdakarya.

Ganda, Y.1987. Petunjuk Praktis Cara Mahasiswa Belajar di Perguruan Tinggi. Jakarta: Grasindo. 